
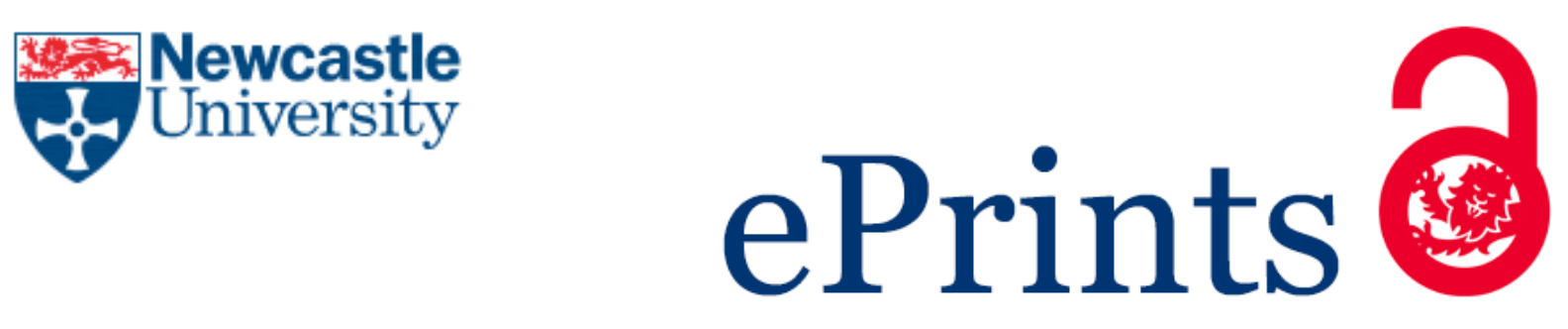

Archer DR, Parkin G, Fowler HJ.

Assessing long term flash flooding frequency using historical information.

Hydrology Research 2016, 47(2)

DOI: http://dx.doi.org/10.2166/nh.2016.031

\title{
Copyright:
}

This is the authors' accepted manuscript of an article that was published in its final definitive form by IWA Publishing, 2016.

DOI link to article:

http://dx.doi.org/10.2166/nh.2016.031

Date deposited:

$19 / 08 / 2016$

Embargo release date:

09 September 2016

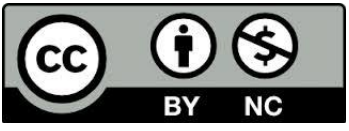

This work is licensed under a Creative Commons Attribution-NonCommercial 3.0 Unported License 


\section{Assessing long term flash flooding frequency using historical information}

David R. Archer ${ }^{1,2, *}$ Geoff Parkin ${ }^{2} \&$ Hayley J. Fowler ${ }^{2}$

${ }^{1}$ JBA Trust, South Barn, Broughton Hall, Skipton, N Yorks, BD23 3AE.

${ }^{2}$ Water Resources Systems Research Laboratory, School of Civil Engineering and Geosciences, Newcastle University, UK NE1 7RU

*Corresponding author. Address for correspondence (home address): David Archer, 2

Welburn Close, Ovingham, Northumberland, NE42 6BD. Email: davearcher@yahoo.com

Short title: Assessing flash flooding frequency using historical information

Corresponding author. Address for correspondence (home address): David Archer, 2 Welburn

Close, Ovingham, Northumberland, NE42 6BD. Email: davearcher@yahoo.com

\section{ABSTRACT}

Flash floods are distinguished from "normal flooding" by an abrupt onset arising from intense short period rainfall. Historical information based on pre-gauged descriptive information is used to prepare time series of flash floods for Northeast England and Southwest England as decadal numbers of events from 1800. The time series show a minimum in the late twentieth century for both locations. Flash flood frequency is then assessed for three locations in Northeast England by comparing recent extreme floods with historical accounts: 1) an urban pluvial flood in Newcastle in June 2012, 2) a severe flood in September 1968 on the Cotting Burn, a small ungauged tributary of the River Wansbeck, and 3) an extreme rate of rise in river level on the River Wansbeck in August 1994. Although there have been no comparable recent occurrences, several flash floods of equal or greater 
magnitude at the same locations were identified from historical accounts. Using the longer historical record in conjunction with limited recent observations has advantages when assessing the frequency of occurrence of rare events. However, these advantages are tempered by the possibility of non-stationarity in the historical series owing to catchment changes, from natural climatic variability and from potential anthropogenic climate change.

Key words | flash flood, historical information, pluvial flood, risk of recurrence, stationarity 


\section{INTRODUCTION}

Historical information, using pre-gauged descriptive sources, has been widely used to improve estimates of peak flood discharges in rivers, for example in Britain (Bayliss \& Reed 2001), in the United States (US Water Resources Council 1988) and in China (MOWR 1980). A variety of statistical methods has been adopted including maximum likelihood methods (Stedinger \& Cohn 1986) and Bayesian approaches (O'Connell et al. 1998). Two features of such methods and their relevance to flash flood risk are:

(1) The need for a gauged record of reasonable length as a means of scaling the historical record. Historical flood analysis is not usually carried out independently of flood frequency analysis of systematic data. Historical data are used in two ways depending on the availability of data:

- $\quad$ using the full gauged data and quantitative historical discharge data,

- using gauged data with only the number of exceedances above a threshold, where quantitative estimates of historical flood discharges cannot be made (e.g. Macdonald \& Black 2010). Typically the reference threshold is set at the level of the largest gauged flood (e.g. Archer et al. 2007).

(2) An assumption of stationarity throughout the record. There is an implied assumption in assessing flood risk that both the gauged and historical data series (either annual maxima or peaks over a threshold) are stationary series or that deviation from stationarity is insufficient to invalidate the assumption. However, central European studies (e.g. Cyberski et al. 2006; Yiou et al. 2006) recognise that historical data may be non-stationary due to natural climatic variability, notably from extreme historical events caused by severe snowmelt during the Little Ice Age, an unusually cold period extending from the sixteenth to the nineteenth century (Lamb 1972). In addition, global warming is projected to cause significant changes to 
the world's climate, including changes in the climate extremes that produce catchment flooding (Milly et al. 2008).

Before discussing the application of frequency and risk assessment methods used for peak flood discharges to flash floods, a distinction must be drawn between "normal" floods and flash floods. A key feature which distinguishes a flash flood from a "normal" flood is the rapid onset, which can be considered in terms of the time from the initial perception of a flood (by a victim) to the occurrence of a level posing a threat to life and property. The word "flash" implies an event that occurs instantaneously or so quickly that it takes victims by surprise. This short time lag can be referred to as a "threat response time" (Archer \& Fowler 2015). This distinguishes it from a "catchment response time" which is defined as the time from the occurrence of rainfall to a peak level or discharge. A catchment response time of up to 6 hours has been used in some definitions to define a flash flood (Georgakakos 1986); however, threat response times may be nearly instantaneous and are typically measured in minutes in the most serious flash floods.

Peak flood magnitude is not the defining factor. Few people are killed by drowning in slow rising floods (Few et al. 2004) however extreme the peak. In the United States $80 \%$ of all flood-related deaths are attributed to flash floods (NWS 2014). The greatest danger to life is in those flash floods which combine a rapid response time with an extreme magnitude as shown by the examples at Lynmouth in Southwest England in 1952 (Dobbie \& Wolf 1953) and at Louth in eastern England in 1920 (Clark \& Arellano 2004).

Flash floods typically occur on short steep rivers but very rapid rates of rise in upstream tributaries may be transmitted downstream to larger catchments as "walls of water" with very little change in the wave front, where they may endanger life in areas unaffected by the inducing storm rainfall (Archer \& Fowler 2015). Events of sufficient severity to cause risk to life and property also occur from surface water (pluvial floods) in both urban and rural 
locations. Since pluvial floods are those which occur between the impact of rainfall at the ground surface and entry to a watercourse, threat response times from intense short-period rainfall are generally brief. In urban areas water gains velocity on smooth and impermeable surfaces and may be of sufficient depth and velocity to sweep people from their feet. Flash floods and pluvial flood risks have lacked the attention given to flooding from rivers. Although the focus has shifted somewhat following The Pitt Review (Cabinet Office 2008), which analysed the nature and consequences of the 2007 floods and noted that some two thirds of affected properties were flooded by pluvial flooding, historical information has not previously been used to assess the frequency of occurrence of flash flooding.

Using historical information for assessment of comparative magnitude and frequency of occurrence of flash floods on ungauged streams and in urban areas poses more difficulties than for gauged river sites. No official records of flash floods are maintained and hence there are no time series of gauged data or even of occurrence. Small catchments are generally ungauged and the only information with which to judge the severity of an event are descriptive accounts of flood depth and extent, with the possible help of photographs and rainfall measurement in the neighbourhood. Pluvial floods offer even more difficulty as there is no defined channel in which to assess comparative flows. However, rainfall information can be combined with descriptive accounts to enable comparisons to be made of source areas, flood pathways, areas of repeated ponding and general impacts. Therefore only descriptive information can be used to scale recently observed events with historical events.

With respect to flash floods on gauged main rivers, archives of peak flood discharges provided for example by HiFlows UK (Centre for Ecology \& Hydrology, 2016) are of limited use. Databases of rate of rise in river flow and level over short time intervals, most critically over 15 minutes, the shortest interval of measurement, are needed. A national database of rates of rise is currently being developed and analysis shows that the highest peak discharges 
are rarely associated with the most rapid rates of rise. Such information is critical for recent flash floods but descriptive information from regional historical chronologies of flash floods, as developed for this study, is required for historical events.

Assessing flood risk for flash floods shares the uncertainty with gauged peak flows arising from potential deviations from stationarity. Specifically for flash floods arising from intense rainfall, Kendon et al. (2014) showed a projected future intensification of short duration rainfall in summer, with significantly more events exceeding the high thresholds indicative of serious flash flooding. Hence, frequency analysis based only on recent occurrence of flash floods may seriously underestimate the future risks.

This study aims to assess the frequencies of flash flooding over longer time periods than is possible using only gauged records. Flash floods at ungauged locations are also included to provide more credible evidence of both recent and historical trends and periodicities. Three case studies in Northeast England are used to assess such evidence in urban and rural areas.

\section{METHODOLOGY FOR CONSTRUCTING HISTORICAL FLASH FLOOD CHRONOLOGIES}

Historical flash flood chronologies were created for Southwest England comprising the counties of Cornwall and Devon (area $\sim 10,270 \mathrm{~km}^{2}$ ) and for Northeast England covering mainly Northumberland and Durham (area $\sim 6700 \mathrm{~km}^{2}$ ) (Figure 1, inset). Although the focus is on convective storm rainfall and resulting flooding, additional information was also collected for intense frontal rainfall. The overall methodology comprises of keyword searches through searchable databases, combined with manual searches through regional newspaper archives. The combination of these methods proved essential to ensure consistent and comprehensive time series, through use of multiple sources for each event. Only during 
World War II when reporting of extreme environmental events was legally restricted is there a potential for missing critical events. However this does not affect the overall conclusions. The following main sources of information were used:

1. A chronology of flash floods in Northeast England was created as a small component of the research on historical river floods in Land of Singing Waters (Archer 1992). This was used as a starting point for the Northeast England chronology.

2. The web-based British Newspaper Archive (BNA) (www.britishnewspaperarchive.co.uk/) provides a searchable resource from over 12 million pages of British newspapers from the eighteenth century to 1950. The search engine identifies all occurrences of selected words in selected regions and years. The words "flood" and "thunder" were used to identify potential flash flood events (the term "flash flood" originates in the 1930s and could not itself be used).

3. British Rainfall (annually 1860 to 1968) contains listings of "Heavy Falls in Short Periods" usually for periods of less than 3 hours. Early records are primarily based on manual observation of a daily raingauge before and after a storm event. Later records include recording rainfall observations. All such events have been further investigated in newspaper sources. Since short period rainfalls had a limited spatial coverage, days with high daily totals have also been further investigated. It is noted that some severe flash floods occurred without any record of extreme rainfall, presumably because the event was isolated and not covered by any gauge. Similarly heavy rainfall, especially high daily totals, occurred on some occasions without any reported impact of flooding.

4. For the period after 1950, newspaper hard copy and microfilm were inspected in regional and local libraries for months between April and October. In some cases 
libraries provided additional assistance through the culling of newspaper cuttings from regional papers on the subject of floods and climate.

For each event associated meteorological information is assembled, including the occurrence of thunder, lightning or hail (and the size and severity of effects). Impacts of the event are indicated in terms of deaths by drowning, bridge failure, regional extent and severity of flooding to property. Flooding is characterised as river or pluvial (or both) and as urban or rural (or both). The location of the flooding and the severity at individual locations is shown. An indication is given as to the occurrence of rapid short-period rate of rise and whether geomorphological effects have been associated. Detailed information for the three selected examples was derived from these chronologies.

\section{HISTORICAL FLASH FLOOD TIME SERIES}

The chronology of historical flash flood events offers the opportunity to investigate historic time series of flash floods in two regions of England. Given the availability of sources, the chronology is believed to be comprehensive from at least 1850 . Results are summarised in Figure 1 which shows the number of severe convective flash floods per decade in a) Northeast England and b) southwest England. The record is divided between the most extreme events and less extreme (severe) events. Impacts of the most extreme events include deaths by drowning, the destruction of houses, mills, weirs and bridges and flooding of a large number of properties in urban areas, serious erosion and sediment movement in rural locations and very rapid rates of rise on main rivers. Less extreme events include all those in which properties were flooded but other impacts were reported to be less severe than in the most extreme category. Events with limited impacts, for example road and street flooding but not property, were excluded. Given the varying nature of flash flood occurrence, there is a measure of subjectivity in the division between categories of extremity. 
For Northeast England there are sustained high numbers of the most extreme events through the second half of the nineteenth century to 1950 with a peak of the less extreme floods between 1871 and 1900. For Southwest England there are again high numbers of the most extreme events between 1850 and 1900 but an apparent rising trend until 1940 for less extreme floods. However, the most obvious feature of both time series is the sharp decline in the decadal frequency of occurrence from the first to the second half of the twentieth century with the decades from 1971 to 1990 having the lowest number of events in Southwest England in the record from 1850. The tally has again increased for Northeast England since 2000 but the evidence for such a change is less distinct for Southwest England.

In the following section we use historical information to prepare regional chronologies of flash floods for Northeast England and for Southwest England (Figure 1). We then examine the frequency of flash floods for three specific locations of contrasting characteristics based on recent events and the historical chronologies:

1) Pluvial floods in the urban area of Newcastle upon Tyne, comparing the flash flood of June 2012 with historical events.

2) A small lowland tributary of the River Wansbeck, the Cotting Burn, which suffered flooding in 2008 and 2012 and a severe flash flood in 1968 with serious effects in the town of Morpeth.

3) The River Wansbeck, a larger catchment which experienced an extreme rate of rise in river level from an intense upstream storm in August 1994.

\section{Newcastle pluvial floods}

The flood of 28 June 2012 was an exceptional event, covering much of the Tyneside area and parts of south Northumberland and Durham. In Newcastle the rainfall started at about 16:00 with the highest Newcastle storm total of $51 \mathrm{~mm}$ (from a limited number of gauges) of which 
$26 \mathrm{~mm}$ fell in 30 minutes, $32 \mathrm{~mm}$ in 1 hour and $49 \mathrm{~mm}$ in 2 hours (Environment Agency 2012). Rainfall return periods were estimated at up to 130 years for periods between 1 and 2 hours. A total of 377 streets were reported flooded, of which 227 suffered highway damage. Over 500 homes had water in their property and 54 businesses were flooded, forcing $40 \%$ to close temporarily (Newcastle City Council 2013). The flooding which occurred during the evening rush hour caused major disruption to road and rail travel.

Urban rivers reached high peak levels, with the River Team, south of Newcastle, at its highest level in 33 years. Rates of rise in level were more unusual and at some locations provided record rates, with the Ouseburn in east Newcastle showing a rate of rise of 1 metre in 30 minutes. However, no property was flooded from rivers during the storm; all flooding was from surface water (Environment Agency 2012). Rainfall on the higher northern and western parts of the city swept along steep roadways, over drainage gullies, through Newcastle University walkways and into buildings. Flood water reached the city centre by various routes where it continued to flow through main shopping thoroughfares and to form ponds in enclosed depressions. One notable site was an area in Newgate Street adjacent to the Cooperative Building where roads and shops were flooded to more than a metre in depth (Figures 2 and 3).

A natural depression (Figure 3), formerly drained by an unnamed tributary of the Lort Burn but now entirely culverted (Smith \& Yellowley 2015), carries excess surface water from dense urban areas and Leazes Park from the northwest towards Newgate Street. At this point historical buildings have blocked the route of surface water and sub-surface drainage is inadequate to prevent ponding.

Given the lack of official flash flood records, rainfall observations for the Tyneside flood of 2012 suggested a return period of over 100 years (Environment Agency 2012). However, inspection of historical chronology provides evidence for many occasions when 
similar or more severe flooding affected Newcastle, though none within the memory of the majority of present residents. The following accounts of historical floods are selected to allow comparison in terms of rainfall or impact with the storm of June 2012.

An event of far greater magnitude struck Newcastle on 22 June 1941 when $50 \mathrm{~mm}$ rainfall occurred in 35 minutes and $95 \mathrm{~mm}$ in 85 minutes at an unspecified site in Newcastle. Several neighbouring gauges registered more than $60 \mathrm{~mm}$. There are no newspaper accounts of the progress or effects of the flood due to wartime restrictions on reporting. However, in addition to the rainfall record the City Library holds a collection of photographs which mainly show the devastation along an urban watercourse in west Newcastle. Several newspaper reports were inspected for each of the following flood events, notably the Newcastle Journal and the Newcastle Evening Chronicle for events in 1913, 1890 and 1872, and the Newcastle Courant for floods in 1839 and 1833.

On 16 September 1913 a flood occurred with rainfall of $67 \mathrm{~mm}$ in 1 hour 30 minutes on Newcastle Town Moor, again significantly greater than in 2012. Detailed newspaper descriptions of this event show similar pathways of flood flow and location of ponding in the city as in 2012. In the depressed area of Newgate Street practically every shop was flooded. Carts along Newgate Street and Percy Street were axle deep in water. The waters from the high land in Barrack Road and Stanhope Street all converged upon the market and Gallowgate was impassable. Stone flags were torn up and some carried for distances down the road. The Green Market was invaded (see Figure 3 for location).

Repeated thunderstorms occurred on 12 August 1890 with the heaviest storm late in the day at Newcastle. No short period rainfalls are reported but five daily rainfall stations registered totals between 56 and $67 \mathrm{~mm}$. No reference was found to the Newgate Street area but severe flooding was reported in neighbouring urban areas where the water was "feet deep and rushing along like a river". (Imperial units have been retained from historical descriptions 
to avoid spurious impressions of accuracy of metric conversions; 1 foot $=0.305 \mathrm{~m}$ : 1 yard $=3$ feet: 1 inch $=25.4 \mathrm{~mm})$ )

Thunderstorms occurred in many parts of England on 18 June 1872 and were particularly severe over Tyneside where streets and property were flooded all over the city as in 2012. No rainfall measurements were available. Three people were killed by lightning and two boys were carried off their feet by flooding in the street in Gateshead but were rescued. The water rushed down Darn Crook into Newgate Street, Percy Street and the corner of Green Market. The water rose waist high, flooding cellars and lower floors. Some women and children were taken out by the front windows. The widespread flooding was compounded by the occurrence of hailstones and clear ice up to an inch in length. Window panes were broken by hail on nearly every street of the town, and buildings with glass roofs such as the Central Station suffered similarly. As in 2012 and 1913 a large volume of water came from the Town Moor (an open area north of the city centre) and gathered near Barras Bridge (through what is now Newcastle University), rendering the road almost impassable. It then flowed through the city centre damaging shops and cellars.

Dramatic flood impacts are also reported for the 18 June 1839 in the Newcastle Courant. The water came down Darn Crook into Newgate Street in such an immense body that it carried away 30 yards of wall, 9 feet high. In two adjacent streets families were, with difficulty, saved from drowning having to be dragged out of their rooms when they were nearly filled with water. In the front street the water rose up to the height of shop counters which at approximately 1 metre in height appears similar to the flood in 2012 (Figure 2).

In a thunderstorm for "upwards of an hour" on 11 June 1833 houses and shops were filled with water to a depth of more than 2 feet in Newgate Street opposite the Darn Crook. Many other locations were flooded in the lower part of the town. 
Apart from the selected description of comparative impact in Newgate Street, detailed historical accounts are available for other parts of the city. On this basis it was judged that six historical events since the early nineteenth century were of similar magnitude and impact to the flash flood of June 2012, whilst the floods of 1941, 1913 and 1872 were probably greater. The implications for flood frequency and risk assessment are discussed below.

\section{The Cotting Burn Morpeth}

The $5.2 \mathrm{~km}^{2}$ tributary of the River Wansbeck, the Cotting Burn (Figure 4(a)) falls 75 metres in its $5 \mathrm{~km}$ course from its rural headwaters, via a steeply incised wooded channel into the town centre of Morpeth, to its confluence with the River Wansbeck at the downstream end of the town. The urban watercourse has been culverted since at least 1826 through most of the town centre, with only short sections now remaining open within narrow walled channels (Figure 5). As well as the rapid response of the catchment, flooding can be attributed to a lack of capacity to convey flows within the culverted sections. During some events, excessive pressure within the culverted sections has caused discharge through manholes, and the severity of impacts has been exacerbated by blockages, particularly by woody debris from the riparian woodlands.

Morpeth was extensively flooded by snowmelt from the River Wansbeck in 1963 (Archer 1992) when nearly 500 properties were flooded. Flood protection work along the main river was nearing completion when flash flooding on 13 September 1968 from the Cotting Burn caused serious damage. The flood of September 1968 was caused by an intense summer storm when $72 \mathrm{~mm}$ rainfall fell within 4 hours from an almost stationary thundery front extending from Yorkshire to Southwest Scotland. The principal feature of the flood was its rapidity of onset which the Morpeth Herald of 20 September 1968 described as "a solid wall of water smashed its way through parts of Morpeth town centre". The culverted section in the upper part of the town was unable to carry the flood water and the severity of impacts 
was increased due to the backing up, and then collapse, of a high flood wall upstream of Copper Chare. The resulting surface water was joined by surcharge from a partial collapse of the culvert, flowing across Copper Chare and around St James Church, spreading along Howard Terrace and travelling down Wellway into Dacre Street (Figure 4(b)). Further accumulation from the open section, backed up from the surcharged culvert, added to the impacts in the lower reaches along Dark Lane and Staithes Lane before finally discharging into the Wansbeck. Two churches, a school (where a mobile classroom was lifted from its footings), several offices, industries including Swinney's Iron works (Figure 4(b)) and many houses were flooded, some to a depth of 5 feet (the total number was not specified).

At the time there was no official recollection of any previous floods from this source and the 1968 flood was assumed unprecedented. However, a review of flood history showed evidence of two events of a comparable size (Archer 1992). Both events were related to lack of capacity of the culverts. The first of these events occurred on 26 October 1900 as a result of widespread heavy rainfall lasting 16 hours over the Northeast England coast. At Cockle Park (Figure 4(a)) just outside the northern boundary of the Cotting Burn catchment, $79 \mathrm{~mm}$ of rain fell. In spite of the long duration rainfall, the Cotting Burn was reported to have risen so suddenly that there was little time to save possessions. Flooding occurred over a similar area to the 1968 event from upstream of Copper Chare down to Staithes Lane, with flood depths of 5 feet reported at Swinney's iron works on Dacre Street. Again there were reports of collapsed walls, although it is not clear if these caused increased flood damage downstream.

In a second event over a 36-hour period from 31 May to 1 June 1924, prolonged rainfall accompanied by embedded thunderstorms again affected coastal Northeast England causing widespread flooding from main rivers and surface water. Over the 2-day period $105 \mathrm{~mm}$ was recorded at Cockle Park causing flooding from the Cotting Burn as overflow 
from surcharged culverts. There were no reports of rapid onset of flooding but on this occasion the lower reaches were affected by backing up from the river Wansbeck which was also in flood.

A search of newspaper and other sources identified no further historical floods on the Cotting Burn from at least 1850. In addition, from 1968, there were no further comparable events until 2008 when a sequence of three flood events within a four-year period have been severe enough to cause significant property damage in the town centre. All of these resulted from similar lack of capacity in the culverts, with backing up and overflow of water at entrances as well as surcharging manholes. Two of these, in 2008 and 2012, were associated with more widespread flooding over the north of England, and fluvial flooding in Morpeth from the River Wansbeck. The most significant flood event recorded in Morpeth occurred on 6 September 2008 with steady catchment rainfall over 48 hours of $120-125 \mathrm{~mm}$. About 1000 properties overall were affected, mostly from the River Wansbeck, but up to 26 properties were flooded from Cotting Burn. A second event involving both the main river and the Cotting Burn was on 25 September 2012, when a widespread slow-moving frontal system over northern England caused flooding of 19 residential properties from the Cotting Burn. Between these two major floods, a smaller event occurred on 31 January 2010 affecting nine properties (seven residential and two commercial) mainly in the area around Copper Chare. Both the 2010 and the 2012 events involved flood water building up behind walls which subsequently collapsed, with a direct effect on downstream properties.

Although precise comparisons are not possible, it is likely that the September 1968 flood remains the largest in the historical record. The perception that property flooding, such as occurred in 1968, is unprecedented is significantly altered both by the evidence of historical floods and the occurrence of recent ones. Culvert surcharge and overflow is not unique but the combined evidence indicates the occurrence of six events (from both flash 
floods and prolonged rainfall) in a period of about 160 years (since 1850). In spite of remedial channel works and changes in the vulnerability of infrastructure, the culverts remain inadequate to convey flow and serious risks to property remain.

\section{River Wansbeck - wall of water}

The River Wansbeck catchment ( $287 \mathrm{~km}^{2}$ to Mitford Gauging Station) consists predominantly of undulating lowland but with a small area of upland in the Simonside Hills in the headwaters (Figure 6). The highest point is $440 \mathrm{~m} \mathrm{OD}$. The river usually responds slowly to rainfall and high floods typically occur during the winter months. The River Wansbeck has two major tributaries, the River Font and Hart Burn whose combined flow contributes to the Mitford gauging station.

A very dry summer from May to July 1994 was followed by an exceptional thunderstorm which gave daily rainfall totals of $100 \mathrm{~mm}$ at Capheaton in the southwest of the catchment. Hourly rainfall totals of $47.4 \mathrm{~mm}$ occurred at Wallington Hall and $37.6 \mathrm{~mm}$ at Font Reservoir but even more striking was the 15-min total of $30 \mathrm{~mm}$ at Wallington Hall (Archer 1994). A gauging station on the Hart Burn tributary showed a 15-min rise in level of $1.32 \mathrm{~m}$. At Mitford principal gauging station, the 15 -min rise was $1.26 \mathrm{~m}$, with an equivalent increase in discharge from 0.6 to $44.5 \mathrm{~m}^{3} / \mathrm{s}$ (Figure $7(\mathrm{a})$ ). Although the peak flow for the event was small in comparison to the maximum recorded flow at the station of $334 \mathrm{~m}^{3} / \mathrm{s}$, the rapidity of the rise in level constituted a different category of risk from peak flow, given the possibility of fishermen or children at the water's edge or on stepping stones in Morpeth (Figure 5). A plot of the annual maximum 15-min rate of rise at Mitford shows that the 1994 event was an outlier in the series, being more than double the previously experienced rate of rise in a 34-year period (Figure 7(b)). The allocation of a probability or a return period to such an unprecedented event within the gauged series is problematic given the uncertainty in 
the form of the tail of the rate of rise distribution. However, assuming a generalised logistic distribution, the return period of the 1994 15-minute rate of rise was calculated as 140 years.

A search through the flash flood chronology reveals two historical events where descriptions of very rapid rates of rise in the Wansbeck at Morpeth suggest that they were similar or greater than the event in 1994.

On 5 July 1881, following a general heatwave in which temperatures in the south of England reached $34^{\circ} \mathrm{C}$, thunderstorms were reported throughout England. In Morpeth the main rain occurred between 04.00 and 05.00 but continued for 6 hours. There are no rainfall records, but the Morpeth Herald on the 9 July 1881 notes: "It must have been very heavy in the west for near midday the Wansbeck came down in a rolling flood, the wave being 3 or 4 feet deep. It rushed over the weir head at East Mill (Figure 5) and caught a boy who had been 'plodging' (paddling) in the water and would have been carried away had not three men heard his cries and came to his rescue. In less than an hour the river was full from bank to bank, the water reaching to the spring of the arches of the Stone Bridge. Much wreckage was brought down".

An even more severe storm occurred on 7 September 1898, when the greatest ever short period rainfall in the Northeast was recorded at Angerton (Figure 6) where $170 \mathrm{~mm}$ fell in 3 hours. Near the centre of the Wansbeck catchment 18 footbridges were washed away and roads were excavated in gullies to a depth of 4-5 feet (British Rainfall 1898). In Morpeth at $3.45 \mathrm{pm}$ the Wansbeck at Morpeth rose without warning. "It came with a strong head and increased volume so rapidly that it was in a few minutes rolling over the weirheads". (Morpeth Herald 10 September 1898). It continued to rise until $6.30 \mathrm{pm}$ by which time it had spread over properties in low-lying parts of the town. Houses were struck and damaged by lightning. At Sheepwash [downstream from Morpeth] "the Wansbeck rose 8 or 9 feet in an 
incredibly short time and covered footpaths to 3 feet deep" (Morpeth Herald 10 September 1898).

Although there are no precise measurements of rates of change in depth, the descriptions of the approaching flood wave are sufficient to conclude that these two events had wave fronts at least equal in magnitude and probably greater than the event in 1994. In addition, whilst the 1994 flood reached its peak immediately after the wave front, in these two events the water continued to rise for several hours and caused serious flooding in Morpeth. No further events with steeply rising wave front were found in newspaper and other descriptions and the record is probably complete from the middle of the nineteenth century, say 160 years.

\section{DISCUSSION}

\section{Assessing frequency of recurrence for the example locations}

For pluvial flash floods, where there is no previous knowledge of events approaching that magnitude, the opportunities for flood risk assessment are limited to the estimation based on the concurrent short-period rainfall statistics. In the absence of gauged information, the anecdotal "worst in living memory" is too short a time period to judge the rarity of an event or its risk of recurrence. Flood history provides the potential for improving flood risk assessment even in locations subject to pluvial flooding and within small ungauged catchments by identifying past events of equal or greater magnitude.

In the chosen example of Newgate Street, Newcastle upon Tyne (where rainfall statistics suggested a return period of up to 130 years) it was judged that six historical events since the early nineteenth century were of similar magnitude and impact to the flash flood of June 2012, whilst the floods of 1941, 1913 and 1872 were probably greater. Knowledge of comparative historical floods changes the perception of the 2012 flood as "unprecedented in 
living memory" to an event which probably ranges from Rank 4 to Rank 7 in a 200 year period suggesting a return period between 30 and 56 years using the Gringorten (1963) plotting position as recommended by Bayliss \& Reed (2001). However, such an assessment relies on the questionable stationarity of the historical record. Future risk will depend on:

1. The direction of natural variability - whether natural conditions favour a return to the greater frequencies of flash flood occurrence in the late nineteenth and early twentieth century or a continuation of the more benign conditions of the second half of the twentieth century.

2. The influence of increasing global and local temperatures on the intensity and frequency of flash flooding.

With respect to the rapid rate of rise in the River Wansbeck example, frequency analysis based on annual maximum rate of rise statistics from a 34 year gauged record suggests a return period of 140 years. With the addition of two historical occurrences of greater magnitude, the apparently unprecedented event in 1994 becomes the Rank 3 event in approximately 160 years (the start of publication of the local newspaper) and a return period of 62 years is suggested by the Gringorten plotting position formula.

For the small Cotting Burn catchment the 1968 flood remains the most severe on record, although two floods approaching its severity occurred over the period of the historic record. As the largest event in the historical record we consider it unwise to allocate a return period. In addition, the sequence of recent floods suggests either a recent upward trend in natural variability or the impact of increasing temperatures on flood risk.

Extreme recent events on a particular catchment often generate a search for historical analogues. However, a more general historical review can reveal catchment vulnerability to flash flooding where no recent events have occurred. This suggests that methods to define "rapid response catchments" based on recent flood history may miss catchments seriously at 
risk. The historical chronologies developed here are being extended to other areas of the UK, and it is planned that they will be made generally available in a searchable georeferenced format.

\section{Flash flood time series}

An assumption of stationarity - that natural systems fluctuate within an unchanging envelope of variability - has traditionally underlain flood risk estimation. However, global warming is predicted to cause significant changes to the world's climate, including changes in the climate extremes that produce catchment flooding (Milly et al. 2008). Potential nonstationarity in future flood risk has long been recognised in Britain (MAFF 2001). Current Defra/Environment Agency guidance requires all flood management plans to allow for climate change by incorporating, within a sensitivity analysis, an increase in river flows of 20\% for any period between 2025 and 2115 (Crooks et al. 2009). Such advice refers to river flood flows in general and not specifically to flash floods whose climate change response to the forcing factor of convective rainfall may differ from sustained heavy rainfall. The study by Kendon et al. (2014) using a very high resolution climate model with $1.5 \mathrm{~km}$ grid spacing for the UK showed a projected future intensification of short duration rainfall in summer, with significantly more events exceeding the high thresholds indicative of serious flash flooding. Hence, frequency analysis based only on recent occurrence of flash floods runs the risk of underestimating future risks. Stationarity is also not guaranteed in the historic record, which may show low-frequency internal variability (e.g. the Atlantic multi-decadal oscillation). The time series of flash flood events presented here (Figure 1) for Northeast and Southwest England has offered the opportunity to investigate historic natural variability of flash floods.

The evidence from these time series does not support an increasing frequency of occurrence of flash floods in line with increased global temperatures over the last 50 years 
but suggests there is a natural variability whose origins have yet to be determined. Kay et al. (2009) note that underlying current natural variability is critical in assessing the importance of climate change impacts on hydrology. If the last 50 years were to be taken to be representative of an assumed past stable climate then, even without the potential effects of further increase in global temperatures, the frequency of flash floods would be underestimated if natural conditions typical of the last 150 years return.

\section{Is the pattern of variation due to climate or catchment change?}

It may legitimately be asked whether the pattern of change is influenced by the effects of changes in catchment or channel conditions as well as climate forcing factors of rainfall intensity and frequency. With respect to catchment changes, the assessment of the relative magnitude of historical pluvial floods is the most problematic. In urban areas, apart from the absence of a defined channel, there are issues concerned with changes in the urban surface permeability (likely to increase flood risk) and improvements to sub surface drainage (likely to decrease flood risk). However, in extreme events such as described, where the rainfall intensity is far in excess of the design capacity of both current and historical drainage systems, surcharging of sewers and surface flows exceeding gulley capacity leads to ponding of surface water at critical points. The June 2012 event in Newcastle had a peak rainfall return period of over 100 years for durations of between 1 and 2 hours compared with a design return period of no more than 50 years for sewer design (WRC 2012).

In contrast, the catchments of the River Wansbeck and the Cotting Burn are rural agricultural catchments in their flood generating upper reaches. Although links between land use management and flood runoff generation are seen mainly at the field scale (O'Connell et al. 2007; Beven et al. 2008), there has been no unequivocal demonstration of hydrological effects of agricultural land use changes on catchments greater than $10 \mathrm{~km}^{2}$ in the UK (O’Connell et al. 2007). Whilst Archer et al. (2010) showed that the influence of agricultural 
land use change could be detected in rates of change in flow during moderate flood events for the agricultural Axe catchment in Southwest England, the effect deteriorated and disappeared in extreme events when overland flow was generated irrespective of land use. The effects of land use change on flash floods both in the Wansbeck catchment and the Cotting Burn are therefore likely to be minimal.

\section{Is there other evidence for the observed pattern?}

The occurrence of large hail which may be associated with flash flooding indicates the severity of convection. Ancillary data on the occurrence of large hail collected for the flash flood chronology shows for the Northeast a high number of occurrences in the years from 1870 to 1930 with a peak from 1891 to 1900 and a sharp reduction in the period after 1950 with some decades when there were no reported occurrences. Similarly for Southwest England high numbers of occurrences were maintained from 1850 to 1940 with greatly reduced numbers afterwards. Lightning impacts show a similar decline after 1950, though this is likely to be related in part to reduced vulnerability (Elsom 1993).

A pattern of upland flood decline since 1950 has also been identified for the north Pennines using lichen-dated flood deposits (Macklin et al. 1992) and for other upland areas of England and Wales (Foulds et al. 2014), including Dartmoor, Wales and northwest England. Foulds et al. (2014) show a negative correlation between the occurrence of dated boulder berms and the SNAO (Summer North Atlantic Oscillation) which was at its highest since 1850 in the late twentieth century (Folland et al. 2009). The increase in flood occurrence since 2001 (Figure 1) coincides with a falling SNAO, but may also reflect the influence of increased temperatures on the intensification of short duration rainfall (Blenkinsop et al. 2015; Chan et al. 2015). The recent flood behaviour is too short to draw any firm conclusions. 


\section{CONCLUSIONS}

Chronologies of historical flash floods for Northeast and Southwest England indicate strong natural variability, with the second half of the twentieth century showing the lowest frequency of such events. The use of this period as a basis for projection of future flash flood risk is likely to result in serious underestimation even without the expected increase in risk due to rising temperatures.

Historical information on flash flooding has been used to assess the frequency of occurrence of three different kinds of flash floods, a pluvial flood at Newcastle (2012), an intense rainfall event causing a rapid rate of rise on the River Wansbeck (1994) and floods on the small tributary catchment of the Cotting Burn. For the three examples described, historical flash flood information changes the perception of the frequency and risk of occurrence. Events which were believed to be unprecedented were found to have previous occurrences of equal or greater magnitude. In each case (assuming a stationary historical time series) the return period of the observed recent event was reduced and the probability of occurrence increased.

The perception of reduced frequency in the late twentieth century is supported by evidence of the predominant dates of major upland erosional events based on flood deposits. Such studies show significant negative correlation between flash flood frequency and the Summer North Atlantic Oscillation (SNAO) which was at its highest in the second half of the twentieth century. Further investigation of causes of natural variability is clearly required.

The comprehensive historical record provides evidence for flash flood frequency on catchments on which no extreme flash flood events have been recorded in the gauged record. As the evidence from each of the examples shows, long periods of quiescence can foster complacency; historical flood information can help to dispel unwarranted confidence in design flood risk estimates. 


\section{ACKNOWLEDGEMENTS}

This research is part of the SINATRA project which is supported by the United Kingdom NERC Flooding From Intense Rainfall programme (grant NE/K00896X/1). H.J.F. is funded by the Wolfson Foundation and the Royal Society as a Royal Society Wolfson Research Merit Award (WM140025) holder.

\section{REFERENCES}

Archer, D. R. 1992 Land of Singing Waters Rivers and Great Floods of Northumbria. Spredden Press, Ovingham, 217 pp.

Archer, D. R. 1994 Walls of water. Circulation 44, 1-3.

Archer, D. R., Climent-Soler, D. \& Holman, I. 2010 Application of changes in rates of rise and fall in discharge to the assessment of impacts of catchment land use. Hydrol. Res. 41(1), $13-26$.

Archer, D. R. 2010 Applying historical information to flood risk assessment in Northeast England. BHS Third International Symposium, Managing Consequences of a Changing Global Environment, Newcastle.

Archer, D. R. \& Fowler, H. J. 2015 Characterising flash flood response to intense rainfall and impacts using historical information and gauged data in Britain. J. Flood Risk Manage. Published online Jul 2015, DOI: 10.1111/jfr3.12187

Beven, K., Young, P., Romanowicz, R., O’Connell, E., Ewen, J., O’Donnell, G., Holman, I., Posthumus, H., Morris, J., Hollis, J. Rose, S., Lamb, R. \& Archer, D. 2008 Analysis of historical data sets to look for impacts of land use and management change on flood generation. R\&D Technical Report FD2120/TR, DEFRA, London 
Blenkinsop, S., Chan, S. C., Kendon, E. J., Roberts, N. M. \& Fowler, H. J. 2015 Temperature influences on intense UK hourly precipitation and dependency on large-scale circulation. Environ. Res. Lett. 10054021.

British Rainfall (Annual 1860-1991) As Symons British Rainfall (1860-1900). HMSO, London.

Chan, S. C., Kendon, E. J., Roberts, N. M., Fowler, H. J. \& Blenkinsop, S. 2016 Temperature constraints on UK precipitation do not extend to future hottest days. Nat. Geosci. 9, 24-28. doi:10.1038/ngeo2596.

Clark, C. \& Arellano, A. C. V. 2004 The Louth storm and flood after 80 years. Weather 59(3), 71-76.

Crooks, S. M., Kay, A. L. \& Reynard, N. S. 2009 Regionalised impacts of climate change on flood flows: hydrological models, catchments and calibration. Milestone report 1 - Project FD2020, Defra/Environment Agency, 59pp.

Dobbie, C. H. \& Wolf, P. O. 1953 The Lynmouth Flood of August 1952 Proc. Inst. Civil Eng. 3, 522-588.

Elsom, D. M. 1993 Deaths caused by lightning in England and Wales, 1852-1990. Weather 48(3), 83-90.

Environment Agency 2012 The Tyneside Flood 28th June 2012: Hydrological Report. EA Yorkshire \& North East Region Hydrology.

Centre for Ecology and Hydrology $(\mathrm{CEH})$ National River Flow Archive: Peak flow data Available from: http://nrfa.ceh.ac.uk/peak-flow-data Accessed 15 February 2016 Few, R., Ahern, M., Matthies, F. \& Kovats, S. 2004 Floods, Health and Climate Change: A Strategic Review. Working Paper 63, Tyndall Centre for Climate Change Research, University of East Anglia, Norwich, UK, 138 pp. 
Folland, C. K., Knight, J., Linderholm, H. W., Fereday, D., Ineson, S. \& Hurrell, J. 2009 The summer North Atlantic Oscillation: past, present, and future. J. Climate 22, 1082-1103. Foulds, S. A., Macklin, M. G. \& Brewer, P. A. 2014 The chronology and the hydrometeorology of catastrophic floods on Dartmoor, South West England. Hydrol. Process. 28(7), 3067-3087.

Georgakakos, K. P. 1986 On the design of national, real-time warning systems with capability for site-specific, flash-flood forecasts. Bull. Am. Meteor. Soc. 67, 1233-1239. Gringorten, I. I. 1963 A plotting rule for extreme probability paper, J. Geophys. Res. 68(3), $813-814$.

Kay, A. L., Davies, H. N., Bell, V. A. \& Jones, R. G. 2009 Comparison of uncertainty sources for climate change impacts: flood frequency in England. Clim. Change 92(1-2), 4163.

Kendon, E. J., Roberts, N. M., Fowler, H. J., Roberts, M. J., Chan, S. C. \& Senior, C. A. 2014 Heavier summer downpours with climate change revealed by weather forecast resolution model. Nat. Clim. Chang. 4, 570-576.

Lamb, H. H. 1972 Climate: present, past and future, vol. 1. Fundamentals and Climate Now. Methuen, London.

Macdonald, N. \& Black, A. R. 2010 Reassessment of flood frequency using historical information for the River Ouse, York, UK. Hydro. Sci. J. 55, 1152-1162.

Macklin, M. G., Rumsby, B. T. \& Heap, T. 1992 Flood alluviation and entrenchment: Holocene valley floor development and transformation in the British uplands. Geol. Soc. Am. Bull. 104, 631-643.

MAFF 2001 Flood and coastal defence project appraisal guidance: Overview. MAFF, Flood and Coastal Defence with Emergencies Division, May 2001. 42pp. 
Milly, P. C. D., Betancourt, J., Falkenmark, M., Hirsch, R. M., Kundzewicz, Z. W.,

Lettenmaier, D. P. \& Stouffer, R. J. 2008 Stationarity is dead: whither water management?

Sci. Clim. Chang. Pol. Forum 319, 573-574.

Ministry of Water Resources 1980 Standard method for flood quantile estimation procedure. Min Water Resources Power Ind SDJ 22-79, Water Resources Publishing House, Beijing (in Chinese).

Newcastle City Council 2013 Summer 2012 Flooding in Newcastle upon Tyne, NCC.

Northumberland County Council 2014 Multi-Agency Flood Plan, Section 2.1, Flood Action Plan v 5.2, NCC, 184pp.

Northumbrian River Authority 1969 Cotting Burn Flood Bypass, Morpeth. Engineer's report. NRA.

NRC (National Research Council) 1988 Estimating PROBABILITIEs of Extreme Floods:

Methods and Recommended Research. National Academy Press, Washington DC.

O’Connell, E., Ewen, J., O’Donnell, G. \& Quinn, P. 2007 Is there a link between agricultural land use management and flooding? Hydrol. Earth Syst. Sci. 11(1), 96-107.

Smith, K. \& Yellowley, T. 2015 The Story of the Tyne and the Hidden Rivers of Newcastle. Tyne Bridge Publishing, Newcastle upon Tyne.

WRC 2012 Sewers for Adoption, 7th edn. - A Design and Construction Guide for Developer, WRC Plc, Swindon.

NWS (National Weather Service) 2014 Summary of Natural Hazard Statistics in the US.

NWS Report, Office of Climate, Water and Weather Services, NWS/NOAA. Available from: www.nws.noaa.gov/om/hazstats.shtml. Accessed: 7 January 2016.

First received 20 January 2016; accepted in revised form 22 January 2016. Available online 